Chirurgia (2017) 112: 378-386

No. $4, \quad$ July - August

Copyright@ Celsius

http://dx.doi.org/10.21614/chirurgia.112.4.378

\title{
Immediate Versus Delayed Breast Reconstruction for Postmastectomy Patients. Controversies and Solutions
}

\author{
Cristina Iulia Filip ${ }^{1}$, Cristian Radu Jecan ${ }^{1,2}$, Laura Raducu ${ }^{1,2}$, Tiberiu Paul Neagu ${ }^{1,3}$, Ioan Petre Florescu ${ }^{1}$ \\ 'University of Medicine and Pharmacy "Carol Davila", Bucharest, Romania \\ 2Department of Plastic and Reconstructive Surgery, Clinical Emergency Hospital "Prof.Dr. Agrippa Ionescu", Bucharest, Romania \\ ${ }^{3}$ Department of Plastic and Reconstructive Surgery, Clinical Emergency Hospital of Bucharest, Romania
}

Corresponding author:

Filip Cristina lulia, MD, PhD student

Hyperclinica MedLife Grivita

Plastic Surgery Department Calea Grivitei, No. 365, District 1

010719, Bucharest, Romania

E-mail: kristine_filip@yahoo.ro

\section{Rezumat \\ Reconstructia imediată versus reconstrucția întârziată a sânului pentru pacientele cu mastectomie. Controverse și soluții}

Reconstrucția de sân implică două decizii majore: alegerea momentului optim şi a tehnicii adecvate de reconstrucție pentru fiecare pacientă, luând în considerare complicațile şi riscurile care pot rezulta în urma acestor decizii. Prin selectarea atentă a pacientelor şi individualizarea reconstrucției de sân, riscurile şi complicațiile acestei proceduri pot fi minimizate, cu rezultat estetic bun şi satisfacție ridicată în rândul pacientelor. Reconstrucția de sân poate fi realizată prin 3 modalități distincte: reconstrucția imediată - la momentul mastectomiei, reconstrucția secundară - la finalizarea tratamentului adjuvant şi reconstrucția imediat-întârziată care utilizează ambele metode precedente - include expansiunea tisulară la momentul mastectomiei şi reconstrucția definitivă la finalizarea tratamentului adjuvant. Strategiile perfecționate timp de decenii în chirurgia reconstructivă a sânului au făcut posibilă reconstrucția imediată a sânului oferind pacientelor şansa de a se recupera după o intervenție de mastectomie cu un nou sân reconstruit. Deşi nu toate pacientele aleg reconstrucția sânului, procentele celor care optează pentru reconstrucție sunt în continuă creştere, iar tehnici noi şi îmbunătățite se dezvoltă rapid.

Cuvinte cheie: cancer de sân, mastectomie, reconstrucție de sân, conservarea tesutului cutanat, implant mamar 


\begin{abstract}
When considering breast reconstruction, two main decisions have to be made: optimal timing and appropriate reconstruction technique,that would best suit each patient, while also taking into consideration the complications and risks that these decisions might lead to. By careful patient selection and individualized breast reconstruction approach, the risks and complications of the procedure can be minimized, while attaining successful aesthetic outcomes and high patient satisfaction. Breast reconstruction can be performed in three different settings: immediate reconstruction - at the time of mastectomy; delayed reconstruction - after the completion of the adjuvant treatment and in a delayed-immediate setting that uses both previous methods includes tissue expansion at the time of mastectomy and definitive reconstruction performed after completion of the adjuvant treatment. The strategies perfected for decades in breast reconstructive surgery have now made breast reconstruction more possible than ever, thus offering patients the chance to recover after a mastectomy procedure with a new reconstructed breast. Although, the choice of breast reconstruction is not adressed by all breast cancer patients, rates are gradually expanding while new and improved techniques are rapidly developing.
\end{abstract}

Key words: breast cancer, mastectomy, breast reconstruction, skin-sparing, breast implant

\section{Introduction}

Presently, breast reconstruction is considered an important step in the management of breast cancer as it not only brings shape to a new breast, but restores the patient's body image and quality of life, while reducing the psychological anxiety that a mastectomy procedure causes $(1,2,3)$. Although the subject of delayed versus immediate breast reconstruction is still controversial, many studies have found that immediate breast reconstruction is oncologically safe for carefully selected pacients $(1,4,5,6)$.

Until 1980, breast reconstruction was considered oncologically safe only when 2 or more years hadpassed after the mastectomy $(7,8)$. Presently, although notable advancements have been made in both immediate and implant-based breast reconstructions, the proportion of delayed reconstructions is still superior to the immediate procedures performed at the time of mastectomy. Moreover, there is a tendency for larger hospitals with high number of patients to perform more immediate reconstructions, as surgeons perform it on a regular basis (9). Accordingly, statistics prove that there is an anual 5\% increase in the rate of immediate breast reconstructions, with $37,8 \%$ of reconstructions being reportedin 2013 as immediate (10).

Currently, the management of breast cancer treatment and reconstruction includes new directions like bilateral and prophylactic mastectomy, as well as skin-sparing and nipplesparing mastectomywhich are frequently performed in an immediate reconstruction setting. At the same time, the indications for radiotherapy have been extendedfor some patients with early breast cancer (11),in the detriment of immediate breast reconstruction surgery, leading not only to better technique and planning for radiotherapy adjuvant treatment, but also to improved algorithms for implantbased and autologous breast reconstructions $(12,13,14,15,16)$.

\section{Pitfalls and Solutions for Choosing the Optimal Timing and Technique for the Breast Reconstruction Procedure}

Patient selection is of great importance when deciding the optimal timing for the breast reconstruction. Whether a patient's breast reconstruction is delayed or immediate depends upon a multitude of variables that 
have to be considered like: cancer stage, tumour size and location, status of the axillary sentinel lymph node, smoking habit, body constitution, history of previous surgeries and radiotherapy, planned radiotherapy or chemotherapy, existing comorbidities and the patient's informed preference $(11,17)$.

The main issue that interferes with immediate breast reconstruction is the uncertainty of post-mastectomy radiotherapy, which if required can lead to significant risks and complications.Generally, patients who are eligible for immediate breast reconstruction are diagnosed with stage I breast cancer, havea good cancer prognosis, a negative sentinel lymph node and no supposed requirement of axillary lymphadenectomy surgery or radiotherapy treatment (11). Some patients with stage II and most patients with stage III of breast cancer have a high risk for postmastectomy radiotherapy and current guidelines recommend breast reconstruction in a delayed or delayedimmediate setting for this category of patients (11).

Still, there are certain preoperative investigations that can better assess the radiotherapy requirement in some of the stage II patients, thus allowing them to benefit from an immediate breast reconstruction. The most accurate investigation that can predict radiotherapy, remains the lymphatic mapping with sentinel lymph node biopsy performed preoperatively which can guide the decision making process for immediate breast reconstruction $(18,19,20)$. Also, a matter of debate is the radiotherapy indication depending on the number of positive lymph nodes $(18,21,22,23)$. There is a generally accepted indication for radiotherapy when 4 or more lymph nodes are involved, but in $85 \%$ of patients a positive sentinel lymph node may be the only positive lymph node present.

Moreover, recent studies have proved that to better prevent locoregional reccurence and improve survival rates, radiotherapy should also be considered for patients with one or more positive lymph nodes $(24,25,26,27,28)$. Generally, if a positive sentinel lymph node results at the preoperative investigations, then radiotherapy is predicted and it is recom- mended to avoid an implant-based or definitive autologous reconstruction and opt for the placement of a tissue expander at the time of mastectomy, in a delayed-immediate setting. In spite of these assessment methods, the absolute indication for radiotherapy is provided only after the definitive pathologic exam,as the tumor extension inside the breast parenchyma is another point to be considered when deciding the need for radiotherapeutic protocol (11).

\section{Main Principles and Controversies for Breast Reconstruction Surgery Associated with Radiotherapy}

In spite of the advancements made, outstanding results are difficult to achieve in immediate implant-based reconstructions followed by adjuvant radiotherapeutic treatment. The reconstruction challenges that arise after a radiotherapy treatment are determined by the various tissular transformations it causes as intense fibrosis and compromised vascular perfusion that eventually lead to a wide range of complications (29).

It is generally believed that patients who are considered for postmastectomy radiotherapy are better served by delayed reconstruction, as immediate reconstruction could influence not only the aestheticoutcome but also the delivery of radiotherapy (30). Firstly, the aesthetic complications that might arise after radiotherapy performed on a reconstructed breast include capsular contracture and fibrosis as reported by Javaid (31), but also implant loss, fat necrosis and arhitectural distortion as reported by Kronowitz (32). Nevertheless, in a study performed by Parsa who compared results for bilateral breast reconstruction patients who received radiotherapy unilaterally and implantbased breast reconstructions bilaterally, it was proven that in cases where the skin modifications caused by radiotherapy were low to moderate, final results of implant-based breast reconstructions were similar in the irradiated and the nonirradiated breast (33,34). Consequently, implant-based breast reconstruction is not a complete contraindication in patients receiving radiotherapy (35) and good results can be obtained with additional 
fat grafting procedures, but it is usually recommended to opt for an autologous breast reconstruction for patients with moderate to severe skin flap changes following radiotherapy $(34,36)$. Secondly, there is the issue of compromised delivery of radiotherapy, especially to the internal mammary lymph nodes and chest wall (37), caused by the interposition of a flap or implant as proved by Motvani in 52 $\%$ of patients with immediate breast reconstruction and argued by Koutcher (38) who found a $97 \%$ control rate for a 30-months period. Although, traditionally believed that an immediate or delayed-immediate breast recons-truction with tissular expansion at the time of mastectomy can negatively influence the delivery and dosimetry of the radiotherapy treatment, numerous studies have currently demonstrated otherwise and this issue is no longer considered in the decision-making process $(18,39,40,41,42)$.

We believe that although implant-based breast reconstruction is easier to achieve, in patients that receive radiotherapy treatment, autologous reconstruction should be considered as a first-line reconstructive option. This approach avoids the complications of immediate implant-based reconstructions like capsular contracture, implant infection and extrusion and grants for a more natural and aesthetic outcome of the reconstructed breast. Nevertheless, this option should be assessed in the light of the patient's informed wish as well as taking into account any additional comorbidities and risk factors that could limit a patient's ability to undergo complex breast reconstruction procedures (1).

\section{Immediate Breast Reconstruction}

Immediate breast reconstruction has been reported by numerous studies as a safe and viable procedure for patients that are not considered for adjuvant radiotherapeutic treatment. The main advantages include the aesthetic outcome determined by a wellpreserved skin envelope which grants a more natural shape and contour to the reconstructed
Table 1. Advantages of immediate implant-based breast reconstruction (1)

\begin{tabular}{l} 
1. No donor site morbidity or additional scars \\
2. A single-stage surgery at lower overall costs \\
3. Short surgical time and recovery \\
4. Psychosocial benefit and faster social reintegration \\
5. Similar color, texture and sensation of the skin flaps \\
\hline
\end{tabular}

breast (43) and the psychosocial well-being that an immediate breast reconstruction can bring to a patient in the postmastectomy stage (Table 1).

Implant-based breast reconstruction, although a controversial field, is the most frequently performed breast reconstruction, with $75 \%$ of all breast reconstructions performed in the USA being implant-based (44).

This high demand is caused by a multitude of factors like the increase in number of both curative and prophylactic mastectomies in the context of surgical technique refinements like nipple-sparing or skin-sparing mastectomy (45), improvements in bioprosthetic technology and new tissue substitutes with predictable and better aesthetic outcomes (Fig. 1).

Implant-based breast reconstruction can be performed in an immediate one-stage setting with a direct to implant technique or a delayed setting for which a tissue expander is placed in a subpectoral pocket and once adequate expansion has been achieved canbe replaced with a definitive implant.

Most frequently, implant-based breast reconstruction is an appropriate option for

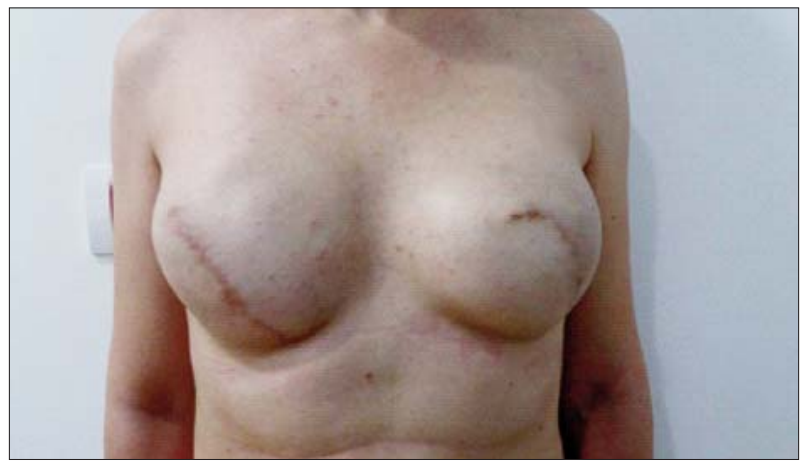

Figure 1. Skin-sparing bilateral mastectomy with immediate bilateral implant-based breast reconstruction 
patients with small to moderate sized breasts and low degree of ptosis. Also, additionally to the implant a tissular substitute like a biological matrice or synthethic mesh can be used for support (17). Further, when deciding upon a breast reconstruction technique, it is aways important to establish preoperatively the patient's expectations of contour, sensation, firmness and consistency of the new-breast as these factors can sometimes lead to reduced patient satisfaction in an implant-based breast reconstruction (47).

Although implant-based breast reconstruction is the most widely used reconstructive procedure, studies worldwide have proved that this approach presents with higher complication rates than autologous reconstructions (48) (Table 2). Implant-based breast reconstruction complications can be the result of variable localrisk factors like very large breasts (> $750 \mathrm{~g}$ ), increased length from sternal notch to nipple $(>26 \mathrm{~cm})(49)$, high implant volume (> $400 \mathrm{ml})$ (50), along with systemic factors liketype 2 diabetes, obesity (51), hypertension, smoking status and an age greater than 65 years (52). Besides, Tamoxifen as an antagonist for aestrogen receptors is associated with high risk of reconstructive failure in implant-based breast reconstruction (53). In fact, revision surgeries after immediate breast reconstruction are more common than after delayed breast reconstruction ( $57 \%$ for IBR vs. $27 \%$ for DBR), with a risk as high as 40,4\% for developing capsular contrac-

Table 2. Contraindications of immediate implant-based breast reconstruction (1)

1. Tumor infiltration to the skin flap or chest wall muscles

2. Risk of complication that would delay the adjuvant treatment scheme (especially in young patients with aggressive tumors or/and positive sentinel lymph node biopsy)

3. Psychological issues or unreasonable expectations for the breast reconstruction

4. Previous irradiation to the chest wall (in case of reccurence)

5. Smoking status (higher risk of skin flap necrosis and infection)

6. Severe breast hypertrophy or morbid obesity (poor aesthetic outcome)

7. High levels of fibrinogen, prothrombin and factors VII, VIII, IX and X

8. High risk of infection or implant extrusion/exposure ture after an immediate reconstruction and less than $17 \%$ after a delayed breast reconstruction (54).

Firstly, early complications with a reported incidence of 5,8\% (52) include hematoma (1-2\%) (54), seroma, infection (1-24\%) (56) and skin flap necrosis (2\%), but also delayed healing, failed expansion, displacement or implant explantation (57). Likewise, late complications may include periprosthetic capsular contracture grade III-IV Baker, infection, implant exposure or extrusion and more frequently encountered implant rippling $(6,6 \%)(1)$.

\section{Delayed Breast Reconstruction}

Delayed breast reconstruction is considered a good option for patients who have increased oncologic risk or present with indication for radiotherapy. Namely, delayed breast reconstruction is required when there is reduced skin flap perfusion caused by either the mastectomy procedure (58) or associated comorbidities like cardiopulmonary disease, diabetes, obesity or smoking (1). In fact, autologous breast reconstruction is the most frequently considered technique in a delayed setting, once clean margins have been established and adjuvant treatment completed $(1,59)$.

Autologous breast reconstruction includes a wide range of flaps, from the latissimus dorsi flap, the transverse rectus abdominis flap, the deep inferior epigastric perforator flap to the less elected flaps like the gluteal artery perforator flap or the upper gracillis flap (60).

The latissimus flap, usually combined with a definitive implant for breast reconstruction, is the most adequate flap for patients with diabetes or for smokers (61), as it is associated with very few complications (62). Moreover, it is a suitable flap for thin patients, who have a history of abdominal surgeries or intend to carry a future pregnancy (61). (Figs. 2, 3)

For patients with large breasts, evident ptosis and sufficient abdominal tissue, good options to consider would be the transverse rectus abdominis flap (as a pedicled or free myocutaneous flap) or the deep inferior epigastric perforator flap (based entirely on the 


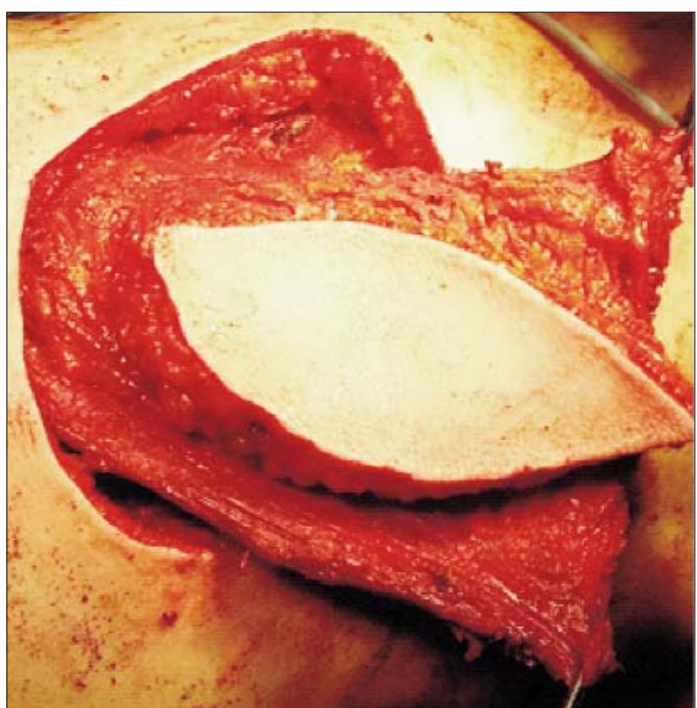

Figure 2. Latissimus dorsi flap at the donor site

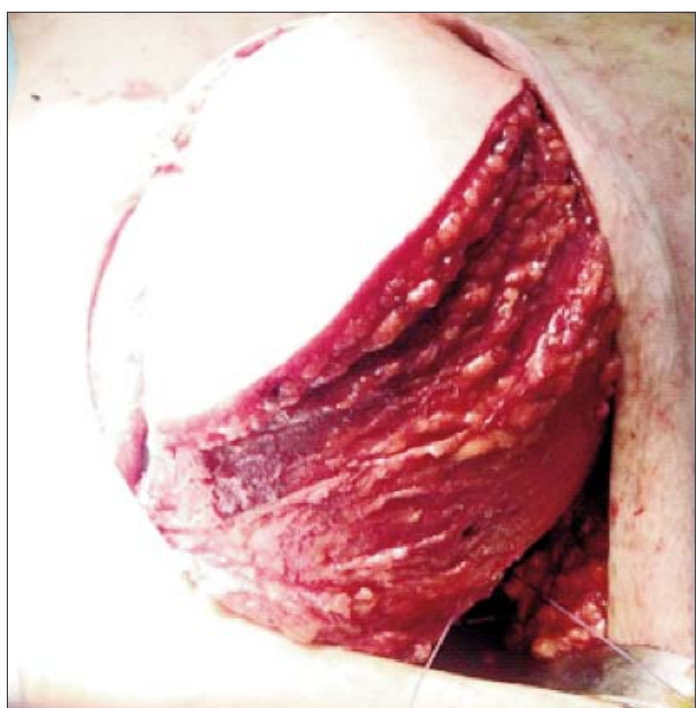

Figure 3. Latissimus dorsi flap at the recipient site, covering the definitive breast implant perforators of the deep inferior epigastric artery) $(63,64)$, as with these flaps the reconstructed breast can resemble closely the native breast. However, this is not a good option for obese patients that present with high risk of fat necrosis and impaired wound-healing $(11,65)$ or for patients with significant comorbidities that could increase the risk of complications. For smoking patients it is advisable that they cease smoking at least 3 months prior to the breast reconstruction procedure (66).

\section{Delayed-immediate Breast Reconstruction}

A solution to the controversial issues of breast reconstruction in association with radiotherapy was advocated by MD Anderson Cancer Center who in 2004 reported a different protocol named „delayed-immediate reconstruction”, destined for patients who might be considered for radiotherapy treatment once the final pathologic result is obtained (67). Usually, these patients have stage II breast cancer with one or more positive lymph-nodes at biopsy, evident microcalcifications on the mammography and/or apparent multicentric condition on the ultrasonography (11).

Delayed-immediate approach involves a skin-sparing mastectomy which is followed by the placement of an expander in the subpectoral pocket. This expander will be deflated during the radiotherapy treatment and inflated again once the radiotherapy is completed. After the tissue expansion is finished, there is a waiting period of 4-6 months that is followed by a breast reconstruction with an autologous flap and rarely if local conditions are favourable with a definitive implant (Fig. 4).

This algorithm permits the preservation of the skin envelopewhile reducing complication rates from $38 \%$ which constitutes the rate for traditional delayed flap reconstruction to a 26 $\%$ rate for delayed-immediate reconstruction

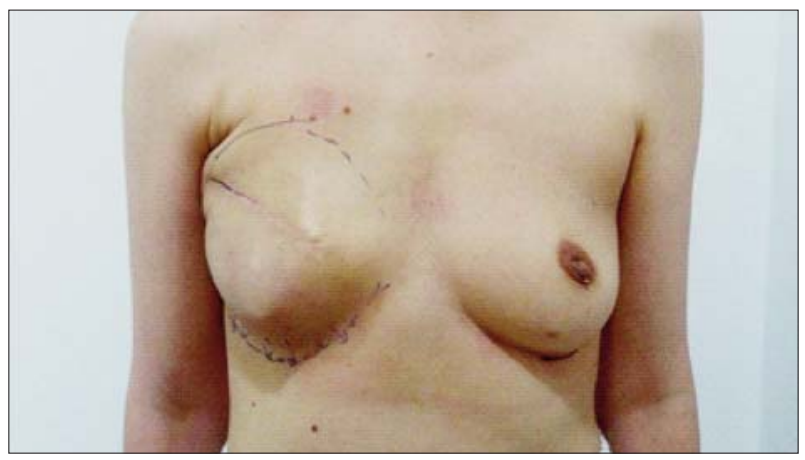

Figure 4. Delayed-immediate breast reconstruction with completed tissular expansion after radiotherapy treatment (before placement of definitive breast implant) 
with autologous flap (68). Moreover, if the final pathologic exam contradicts the need for radiotherapy, then tissue expansion can be followed after the first 2 weeks by the placement of a definitive breast implant in the context of a well preserved skin envelope (11).

\section{Conclusion}

The management of breast cancer treatment and reconstruction must adress both the longterm oncological safety and the final aesthetic outcome. These can only be achieved if the patient's assessment and treatment options are analyzed within a multidisciplinary team composed of the oncologist, the general surgeon, the radiotherapy specialist, the pathologist, the plastic surgeon and the patient herself who must be sufficiently well-informed to be able to participate in the decision-making step concerning the course of her treatment and reconstruction process.

\section{Conflict of Interest}

The authors have no conflict of interest to declare.

\section{Authors' Contribution}

All authors have contributed equally in all stages of this article's development.

\section{References}

1. Urban C, Rietjens M. Oncoplastic and reconstructive surgery of the breast. Springer (Italy); 2013.

2. Miller MJ. Immediate breast reconstruction. Clin Plast Surg. 1998; 25(2):145-56.

3. D'Souza N, Darmanin G, Fedorowicz Z. Immediate versus delayed reconstruction following surgery for breast cancer. Cochrane Database Syst Rev. 2011;(7):CD008674. doi: 10.1002/14651858.CD008674. pub2.

4. Langstein HN, Cheng MH, Singletary SE, Robb GL, Hoy E, Smith TL et al. Breast cancer recurrence after immediate reconstruction: patterns and significance. Plast Reconstr Surg. 2003;111(2):712-20; discussion 721-2.

5. Newman LA, Kuerer HM, Hunt KK, Ames FC, Ross MI, Theriault R et al. Feasibility of immediate breast reconstruction for locally advanced breast cancer. Ann Surg Oncol. 1999;6(7):671-5.

6. O'Brien W, Hasselgren PO, Hummel RP, Coith R, Hyams D, Kurtzman L et al. Comparison of postoperative wound complications and early cancer recurrence between patients undergoing mastectomy with or without immediate breast reconstruction. Am J Surg. 1993;166(1):1-5.

7. Petit JY, Lê MG, Mouriesse H, Rietjens M, Gill P, Contesso G, et al. Can breast reconstruction with gel-filled silicone implants increase the risk of death and second primary cancer in patients treated by mastectomy for breast cancer? Plast Reconstr Surg. 1994;94(1):115-9.

8. Petit JY, Lê M, Rietjens M, Contesso G, Lehmann A, Mouriesse H. Does long-term exposure to gel-filled silicone implants increase the risk of relapse after breast cancer? Tumori. 1998:84(5):525-8.

9. Hershman DL, Richards CA, Kalinsky K, Wilde ET, Lu YS, Ascherman $J A$, et al. Influence of health insurance, hospital factors and physician volume on receipt of immediate post-mastectomy reconstruction in women with invasive and non-invasive breast cancer. Breast Cancer Res Treat. 2012:136(2):535-45. doi: 10.1007/s10549-012-2273-4. Epub 2012 Sep 29.

10. Albornoz CR, Bach PB, Mehrara BJ, Disa JJ, Pusic AL, McCarthy CM, et al. A paradigm shift in U.S. Breast reconstruction: increasing implant rates. Plast Reconstr Surg. 2013; 131(1):15-23. doi: 10.1097/ PRS.0b013e3182729cde.

11. Kronowitz SJ, Kuerer HM. Advances and surgical decision-making for breast reconstruction. Cancer. 2006;107(5):893-907.

12. Clemens MW, Kronowitz SJ. Current perspectives on radiation therapy in autologous and prosthetic breast reconstruction. Gland Surg. 2015; 4(3):222-31. doi: 10.3978/j.issn.2227-684X.2015.04.03.

13. Keating NL, Landrum MB, Brooks JM, Chrischilles EA, Winer EP, Wright $\mathrm{K}$, et al. Outcomes following local therapy for early-stage breast cancer in non-trial populations. Breast Cancer Res Treat. 2011; 125(3):803-13. doi: 10.1007/s10549-010-0865-4. Epub 2010 Apr 8.

14. Beahm EK, Walton RL. Issues, Considerations, and Trends in Bilateral Breast Reconstruction. Plast Reconstr Surg. 2009;124:1064-76.

15. Spear SL, Shuck J, Hannan L, Albino F, Patel KM. Evaluating long-term outcomes following nipple-sparing mastectomy and reconstruction in the irradiated breast. Plast Reconstr Surg. 2014 May;133(5):605e614e. doi: 10.1097/PRS.0000000000000098.

16. Shirvani SM, Pan IW, Buchholz TA, Shih YC, Hoffman KE, Giordano $\mathrm{SH}$, et al. Impact of evidence-based clinical guidelines on the adoption of postmastectomy radiation in older women. Cancer. 2011;117(20): 4595-605. doi: 10.1002/cncr.26081. Epub 2011 Jun 27.

17. Quinn TT, Miller GS, Rostek M, Cabalag MS, Rozen WM, Hunter-Smith DJ. Prosthetic breast reconstruction: indications and update. Gland Surg. 2016;5(2):174-86. doi: 10.3978/j.issn.2227-684X.2015.07.01.

18. Mannu GS, Navi A, Morgan A, Mirza SM, Down SK, Farooq N, et al. Sentinel lymph node biopsy before mastectomy and immediate breast reconstruction may predict post-mastectomy radiotherapy, reduce delayed complications and improve the choice of reconstruction. Int J Surg. 2012;10(5):259-64. doi: 10.1016/j.jjsu.2012.04.010. Epub 2012 Apr 21.

19. Kronowitz SJ, Robb GL. Breast reconstruction with postmastectomy radiation therapy: current issues. Plast Reconstr Surg. 2004;114(4): 950-60.

20. Recht A, Edge SB, Solin LJ, Robinson DS, Estabrook A, Fine RE et al. Postmastectomy radiotherapy: clinical practice guidelines of the American Society of Clinical Oncology. J Clin Oncol. 2001;19(5):153969.

21. Eifel P, Axelson JA, Costa J, Crowley J, Curran WJ, Deshler A, et al. National Institutes of Health Consensus Development Conference Statement: adjuvant therapy for breast cancer, November 1-3, 2000. J Natl Cancer Inst. 2001;93(13):979-89.

22. Harris JR, Halpin-Murphy P, McNeese M, Mendenhall NP, Morrow M, Robert NJ. Consensus Statement on postmastectomy radiation therapy. Int J Radiat Oncol Biol Phys. 1999:44(5):989-90.

23. Hiraoka M, Mitsumori M, Shibuya K. Adjuvant radiation therapy following mastectomy for breast cancer. Breast Cancer. 2002;9(3):1905.

24. Truong PT, Olivotto IA, Kader HA, Panades M, Speers CH, Berthelet E. Selecting breast cancer patients with T1-T2 tumors and one to three positive axillary nodes at high postmastectomy locoregional recurrence risk for adjuvant radiotherapy. Int J Radiat Oncol Biol Phys. 2005;61(5):1337-47.

25. Fodor J, Polgár C, Major T, Németh G. Locoregional failure 15 years after mastectomy in women with one to three positive axillary nodes 
with or without irradiation the significance of tumor size. Strahlenther Onkol. 2003;179(3):197-202.

26. Cheng JC, Chen CM, Liu MC, Tsou MH, Yang PS, Jian JJ et al. Locoregional failure of postmastectomy patients with 1-3 positive axillary lymph nodes without adjuvant radiotherapy. Int J Radiat Oncol Biol Phys. 2002:52(4):980-8.

27. Recht A, Gray R, Davidson NE, Fowble BL, Solin LJ, Cummings FJ et al. Locoregional failure 10 years after mastectomy and adjuvant chemotherapy with or without tamoxifen without irradiation: experience of the Eastern Cooperative Oncology Group. J Clin Oncol. 1999;17(6): 1689-700.

28. Taghian A, Jeong JH, Mamounas E, Anderson S, Bryant J, Deutsch M, et al. Patterns of locoregional failure in patients with operable breast cancer treated by mastectomy and adjuvant chemotherapy with or without tamoxifen and without radiotherapy: results from five National Surgical Adjuvant Breast and Bowel Project randomized clinical trials. J Clin Oncol. 2004;22(21):4247-54. Epub 2004 Sep 27.

29. Pomahac B, Recht A, May JW, Hergrueter CA, Slavin SA. New trends in breast cancer management. Is the era of immediate breast reconstruction changing? Ann Surg. 2006;244(2):282-8.

30. Buchholz TA, Strom EA, Perkins GH, McNeese MD. Controversies regarding the use of radiation after mastectomy in breast cancer. Oncologist. 2002;7(6):539-46.

31. Javaid M, Song F, Leinster S, Dickson MG, James NK. Radiation effects on the cosmetic outcomes of immediate and delayed autologous breast reconstruction: an argument about timing. J Plast Reconstr Aesthet Surg. 2006;59(1):16-26.

32. Kronowitz S, Hunt K, Kuerer H, Strom E, Buchholz T, Ensor $\mathrm{J}$ et al. Immediate versus delayed repair of partial mastectomy defects in breast conservation. Breast Cancer Res. 2009;11(Suppl 1):S8.

33. Parsa AA, Jackowe DJ, Johnson EW, Lye KD, Iwahira Y, Huynh TV, et al. Selection criteria for expander/implant breast reconstruction following radiation therapy. Hawaii Med J. 2009;68(3):66-8.

34. Rykała J, Szychta P, Kruk-Jeromin J. Delayed two-stage breast reconstruction with implants: The authors' recent experience. Can J Plast Surg. 2011;19(3):88-92.

35. Ribuffo D, Monfrecola A, Guerra M, Di Benedetto GM, Grassetti L, Spaziani $E$ et al. Does postoperative radiation therapy represent a contraindication to expander-implant based immediate breast reconstruction? An update 2012-2014. Eur Rev Med Pharmacol Sci. 2015; 19(12):2202-7.

36. Hirsch EM, Seth AK, Dumanian GA, Kim JY, Mustoe TA, Galiano RD, et al. Outcomes of immediate tissue expander breast reconstruction followed by reconstruction of choice in the setting of postmastectomy radiation therapy. Ann Plast Surg. 2014;72(3):274-8. doi: 10.1097/ SAP.0b013e318268a7ea.

37. Buchholz TA, Strom EA, Perkins GH, McNeese MD. Controversies regarding the use of radiation after mastectomy in breast cancer. Oncologist. 2002;7(6):539-46.

38. Koutcher L1, Ballangrud A, Cordeiro PG, McCormick B, Hunt M, Van Zee KJ, Hudis C, Beal K. Postmastectomy intensity modulated radiation therapy following immediate expander-implant reconstruction. Radiother Oncol. 2010;94(3):319-23. doi: 10.1016/j.radonc. 2009.12.003. Epub 2010 Jan 22.

39. Cordeiro PG, Pusic AL, Disa JJ, McCormick B, VanZee K. Irradiation after immediate tissue expander/implant breast reconstruction: outcomes, complications, aesthetic results, and satisfaction among 156 patients. Plast Reconstr Surg. 2004;113(3):877-81.

40. Anderson PR, Hanlon AL, Fowble BL, McNeeley SW, Freedman GM. Low complication rates are achievable after postmastectomy breast reconstruction and radiation therapy. Int J Radiat Oncol Biol Phys. 2004;59(4):1080-7.

41. Behranwala KA, Dua RS, Ross GM, Ward A, A'Hern R, Gui GP. The influence of radiotherapy on capsule formation and aesthetic outcome after immediate breast reconstruction using biodimensional anatomical expander implants. J Plast Reconstr Aesthet Surg. 2006; 59(10):1043-51. Epub 2006 Jun 12.
42. Anderson PR, Freedman G, Nicolaou N, Sharma N, Li T, Topham N et al. Postmastectomy chest wall radiation to a temporary tissue expander or permanent breast implant--is there a difference in complication rates? Int J Radiat Oncol Biol Phys. 2009;74(1):81-5. doi: 10.1016/ j.ijrobp.2008.06.1940. Epub 2008 Sep 25.

43. Albino FP, Patel KM, Smith JR, Nahabedian NY. Delayed versus Delayed-Immediate Autologous Breast Reconstruction: A Blinded Evaluation of Aesthetic Outcomes. Arch Plast Surg. 2014:41(3):26470. doi: 10.5999/aps.2014.41.3.264. Epub 2014 May 12.

44. Spear SL, Meshabi AN. Implant-based reconstruction. Clin Plast Surg. 2007;34(1):63-73; abstract vi.

45. Gerber B, Krause A, Dieterich M, Kundt G, Reimer T. The oncological safety of skin sparing mastectomy with conservation of the nippleareola complex and autologous reconstruction: an extended follow-up study. Ann Surg. 2009;249(3):461-8.

46. Roostaeian J, Pavone L, Da Lio A, Lipa J, Festekjian J, Crisera C. Immediate placement of implants in breast reconstruction: patients selection and outcomes. Plast Reconstr Surg. 2011;127(4):1407-16. doi: 10.1097/PRS.0b013e318208d0ea.

47. Snell L, McCarthy C, Klassen A, Cano S, Rubin L, Hurley K, et al. Clarifying the expectations of patients undergoing implant breast reconstruction: a qualitative study. Plast Reconstr Surg. 2010;126(6): 1825-30. doi: 10.1097/PRS.0b013e3181f44580.

48. Davila AA, Mioton LM, Chow G, Wang E, Merkow RP, Bilimoria KY, et al. Immediate two-stage tissue expander breast reconstruction compared with one-stage permanent implant breast reconstruction: a multi-institutional comparison of short-term complications. J Plast Surg Hand Surg. 2013;47(5):344-9. doi: 10.3109/2000656X.2013. 767202. Epub 2013 Apr 3.

49. Davies K, Allan L, Roblin P, Ross D, Farhadi J. Factors affecting postoperative complications following skin sparing mastectomy with immediate breast reconstruction. Breast. 2011;20(1):21-5. doi: 10.1016/j.breast.2010.06.006. Epub 2010 Jul 8.

50. Bailey MH, Smith JW, Casas L, Johnson P, Serra E, de la Fuente R, et al. Immediate breast reconstruction: reducing the risks. Plast Reconstr Surg. 1989;83(5):845-51.

51. Miller AP, Falcone RE. Breast reconstruction: systemic factors influencing local complications. Ann Plast Surg. 1991;27(2):115-20.

52. Cordeiro PG, McCarthy CM. A single surgeon's 12-year experience with tissue expander/implant breast reconstruction: part I. A prospective analysis of early complications. Plast Reconstr Surg. 2006; 118(4):825-31.

53. Krueger EA, Wilkins EG, Strawderman M, Cederna P, Goldfarb S, Vicini FA, et al. Complications and patient satisfaction following expander/ implant breast reconstruction with and without radiotherapy. Int J Radiat Oncol Biol Phys. 2001; 49(3):713-21.

54. Sullivan SR1, Fletcher DR, Isom CD, Isik FF. True incidence of all complications following immediate and delayed breast reconstruction. Plast Reconstr Surg. 2008;122(1):19-28. doi: 10.1097/ PRS. Ob013e3181774267.

56. Nahabedian MY, Tsangaris T, Momen B, Manson PN. Infectious complications following breast reconstruction with expanders and implants. Plast Reconstr Surg. 2003;112(2):467-76.

57. Clough KB, O'Donoghue JM, Fitoussi AD, Nos C, Falcou MC. Prospective evaluation of late cosmetic results following breast reconstruction: I. Implant reconstruction. Plast Reconstr Surg. 2001;107(7): 1702-9.

58. Nahabedian M. Breast reconstruction in women with breast cancer. 2011. Accessed $21^{\text {st }}$ february 2017 - http://www.uptodate.com/ contents/breast-reconstructionin-women-with-breast-cancer? source=search_result\&search=breast+reconstruction\&selected Title $=1$ * $78 \# \mathrm{H} 16$

59. Alderman AK, Wilkins EG, Kim HM, Lowery JC. Complications in postmastectomy breast reconstruction: two-year results of the Michigan Breast Reconstruction Outcome Study. Plast Reconstr Surg. 2002; 109(7):2265-74.

60. Rosson GD, Magarakis M, Shridharani SM, Stapleton SM, Jacobs LK, 
Manahan MA, et al. A review of the surgical management of breast cancer: plastic reconstructive techniques and timing implications. Ann Surg Oncol. 2010;17(7):1890-900. doi: 10.1245/s10434-010-0913-7. Epub 2010 Mar 9.

61. Hamdi M, Van Landuyt K, Hijjawi JB, Roche N, Blondeel P, Monstrey S. Surgical technique in pedicled thoracodorsal artery perforator flaps: a clinical experience with 99 patients. Plast Reconstr Surg. 2008; 121(5):1632-41. doi: 10.1097/PRS.0b013e31816c3bfa.

62. Kroll SS, Baldwin B. A comparison of outcomes using three different methods of breast reconstruction. Plast Reconstr Surg. 1992;90(3) 455-62.

63. Nahabedian NY, Tsangaris T, Momen B. Breast reconstruction with the DIEP flap or the muscle-sparing (MS-2) free TRAM flap: is there difference? Plast Reconstr Surg. 2005;115(2):436-44; discussion 445-6.

64. Nahabedian MY, Momen B, Galdino G, Manson PN. Breas Reconstruction with the free TRAM or DIEP flap: patient selection, choice of flap, and outcome. Plast Reconstr Surg. 2002;110(2):46675; discussion 476-7.

65. Chang DW, Wang B, Robb GL, Reece GP, Miller MJ, Evans GR, et al. Effect of obesity on flap and donor-site complications in free transverse rectus abdominis myocutaneous flap breast reconstruction. Plast Reconstr Surg. 2000;105(5):1640-8.

66. Padubidri AN, Yetman R, Browne E, Lucas A, Papay F, Larive B, et al. Complications of postmastectomy breast reconstructions in smokers, ex-smokers, and nonsmokers. Plast Reconstr Surg. 2001;107(2):3429; discussion 350-1.

67. Kronowitz SJ, Hunt KK, Kuerer HM, Babiera G, McNeese MD, Buchholz $\mathrm{TA}$, et al. Delayed-immediate breast reconstruction. Plast Reconstr Surg. 2004;113(6):1617-28.

68. Kronowitz SJ. Delayed-immediate breast reconstruction: technical and timing considerations. Plast Reconstr Surg. 2010;125(2):463-74. doi: 10.1097/PRS.0b013e3181c82d58. 